\title{
PENINGKATAN PARTISIPASI DAN HASIL BELAJAR SISWAMELALUI METODE BERMAIN JAWABAN DALAM PEMBELAJARAN IPA KELAS IV SDN 10 KOTO JUA KECAMATAN BAYANG
}

\author{
Alam Suryadi ${ }^{1}$, Wince Hendri ${ }^{2}$, Erwinsyah Satria ${ }^{1}$ \\ Pendidikan Guru Sekolah Dasar \\ Fakultas Keguruan dan Ilmu Pendidikan \\ Universitas Bung Hatta \\ E-mail: suryadi_alam@yahoo.com
}

\begin{abstract}
Abstrak
The purpose of this study was to determine whether the use of the method of playing the answers can increase the participation of students in answering the question, responding to questions and discuss the study of NATURAL SCIENCE. The research is the research action class with the subject grade IV which amounted to 16 people. Research instrument is the observation sheet implementation of the learning process of teachers, student participation, observation sheets and test results of student learning. Results of the research cycle I gained an average of the percentage of participation of students in a discussion ask 46,87\% while on cycle II $71,87 \%$, answering questions on a cycle I $53,12 \%$, while on cycle II $71,87 \%$, and respond to questions on the cycle I $40,62 \%$ while on cycle II $71,87 \%$. This means the target indicator in this research work and implementation of learning the IPA with the method of play took place with good answers. Based on the results of this research, it is recommended that the teacher can use the method to improve the participation response played learn IPA students.
\end{abstract}

Keywords: participation and the results of learning, Playing defense, IPA

\section{A. Pendahuluan}

Pendidikan merupakan usaha Ilmu Pengetahuan Alam (IPA) sadar dan terencana untuk mewujudkan menurut Kurikulum Tingkat Satuan suasana belajar dan proses pembelajaran agar peserta didik secara aktif mengembangkan potensi dirinya sebagaimana dituangkan dalam undangundang No 20 Tahun 2003. Dalam pengembangan potensi siswa Sekolah Dasar (SD) dipelajari berbagai bidang studi, yaitu Matematika, Pendidikan Kewarganegaraan (PKn), Ilmu Pengetahuan Sosial (IPS), Ilmu Pengetahuan Alam (IPA) serta mata pelajaran lainnya. Pendidikan (KTSP) tahun 2006, berkaitan dengan cara mencari tahu tentang alam secara sistematis, sehingga IPA bukan hanya penguasaan kumpulan pengetahuan yang berupa fakta-fakta, konsep-konsep, atau prinsip-prinsip saja tetapi juga merupakan suatu proses penemuan. Pendidikan IPA diharapkan dapat menjadi wahana bagi peserta didik untuk mempelajari diri sendiri dan alam sekitar, serta prospek pengembangan lebih lanjut dalam menerapkannya di dalam kehidupan 
sehari-hari. Proses pembelajarannya menekankan pada pemberian pengalaman langsung untuk mengembangkan potensi agar menjelajahi dan memahami alam sekitar secara alamiah.

IPA merupakan kajian tentang diri sendiri dan alam sekitar. Dengan mempelajari IPA dapat membangkitkan kesadaran siswa dan mendorong kepekaan siswa terhadap diri sendiri dan alam sekitar. Oleh karena itu, para guru IPA dituntut untuk mampu merangsang dan merencanakan pembelajaran IPA sedemikian rupa dengan memperhatikan prinsip dan karakteristik IPA itu sendiri sehingga tujuan pembelajaran IPA dapat tercapai.

Keberhasilan dalam proses belajar mengajar dipengaruhi oleh beberapa unsur. Unsur-unsur tersebut adalah pendidik (guru), peserta didik (siswa), kurikulum, pengajaran, tes, dan lingkungan. Siswa sebagai subjek dalam proses tersebut juga sangat berperan dalam keberhasilan kegiatan belajar mengajar (Sudjana, 2002:2).

Berdasarkan observasi yang peneliti lakukan pada tanggal 10 Januari 2013 di SDN 10 Koto Jua Kecamatan Bayang, di peroleh gambaran bahwa proses pembelajaran IPA masih mengalami kendala-kendala diantaranya adalah partisipasi belajar siswa yang masih rendah. Dalam pembelajaran siswa banyak meribut, tidak memperhatikan guru, sering keluar masuk kelas, tidak mengerjakan latihan. Dalam setiap kali guru mengajukan pertanyaan siswa banyak diam, dan bahkan mereka tidak menghiraukan pertanyaan dari guru tersebut. Sewaktu guru mengadakan diskusi kelompok, hanya beberapa orang yang aktif dalam diskusi tersebut. Selebihnya mereka banyak bermain-main saat diskusi dilaksanakan. Waktu guru memberikan latihan tidak ada keinginan siswa untuk mengerjakan latihan yang berikan oleh guru tersebut.

Berdasarkan hasil ulangan harian siswa pada semester 1 , terlihat bahwa nilai siswa masih banyak di bawah Kriteria Ketuntasan Minimal (KKM). Dari hasil wawancara dengan guru kelas IV yaitu Bapak Asrial. Di peroleh informasi bahwa rendahnya hasil belajar siswa disebabkan oleh beberapa faktor di antaranya siswa kurang berpartisipasi dalam proses belajar mengajar, guru memakai metode ceramah, dan memakai buku paket yang ada, pada waktu guru memberikan pertanyaan, hanya satu atau dua orang yang menjawab pertanyaan guru. Sewaktu guru menjelaskan pelajaran di depan kelas, masih ada siswa yang mengobrol dengan temannya dan ada yang bermenung. Siswa kesulitan karena IPA banyak menuntut siswa untuk banyak ikut serta dalam pembelajaran. 
Keadaan seperti ditunjukkan di atas tentu sangat mengkhawatirkan karena dapat menyebabkan suasana belajar tidak menyenangkan, kurangnya partisipasi siswa dalam belajar, sehingga hasil belajar siswa rendah. Salah satu upaya yang dapat dilakukan guru untuk meningkatkan partisipasi belajar siswa dalam pembelajaran yaitu dengan cara menggunakan model pembelajaran kooperatif tipe Bermain Jawaban. Pembelajaran kooperatif metode Bermain Jawaban adalah pembelajaran yang didahului dengan penyajian materi pembelajaran oleh guru dan siswa dibagi menjadi beberapa kelompok yang mana dari masing-masing kelompok diberi beberapa buah pertanyaan, pertanyaan yang diberikan pada setiap kelompok berjumlah sama, dan guru menyiapkan beberapa buah jawaban yang disimpan guru pada kantong-kantong yang terdapat di depan kelas, jawaban yang disiapkan lebih banyak dibandingkan dengan pertanyaan yang telah disediakan, setiap anggota dari masing-masing kelompok membahas pertanyaan yang telah diberikan oleh guru, kemudian perwakilan dari masing-masing kelompok harus menyocokkan pertanyaan dengan jawaban yang terdapat di depan kelas dan setelah jawaban selesai dibacakan, kelompok yang lain boleh memberi komentar atas jawaban tersebut.
Berdasarkan hal di atas maka peneliti melakukan penelitian dengan judul "Peningkatan Partisiasi dan Hasil Belajar Siswa Melalui Metode Bermain jawaban dalam Pembelajaran IPA di kelas IV SDN 10 Koto Jua Kecamatan Bayang“.

Masalah yang peneliti amati dalam proses pembelajaran berlangsung adalah: (1) Partisipasi belajar siswa yang masih rendah dalam bertanya, menjawab pertanyaan, dan berdiskusi, (2) dalam pembelajaran siswa banyak meribut, tidak memperhatikan guru, (3) siswa sering keluar masuk kelas, tidak mengerjakan latihan, (4) waktu guru memberikan latihan tidak ada keinginan siswa untuk mengerjakan latihan yang berikan oleh guru tersebut, (5) Guru masih dominan menggunakan model pembelajaran konvensional.

Mengingat luasnya ruang lingkup permasalahan serta kemampuan peneliti yang terbatas, maka penelitian ini dibatasi pada: (1) Peningkatan partisipasi siswa dalam bertanya pembelajaran IPA melalui metode Bermain Jawaban di kelas IV SDN 10 Koto Jua Kecamatan Bayang, (2) menjawab pertanyaan pembelajaran IPA melalui metode Bermain Jawaban di kelas IV SDN 10 Koto Jua Kecamatan Bayang, (3) siswa berdiskusi dalam pembelajaran IPA melalui metode Bermain Jawaban di kelas IV SDN 10 Koto Jua Kecamatan Bayang, (4) hasil belajar siswa dalam 
pembelajaran IPA melalui metode Bermain Jawaban di kelas IV SDN 10 Koto Jua Kecamatan Bayang.

Berdasarkan uraian dari latar belakang tersebut di atas, maka rumusan masalah dalam penelitian ini adalah sebagai berikut: (1) Bagaimanakah peningkatan partisipasi bertanya siswa dalam pembelajaran IPA di kelas IV SD Negeri 10 Koto Jua Kecamatan Bayang melalui metode Bermain Jawaban?, (2) bagaimanakah peningkatan partisipasi menjawab siswa dalam pembelajaran IPA di kelas IV SD Negeri 10 Koto Jua Kecamatan Bayang melalui metode Bermain Jawaban?, (3) bagaimanakah peningkatan partisipasi berdiskusi siswa dalam pembelajaran IPA di kelas IV SD Negeri 10 Koto Jua Kecamatan Bayang melalui metode Bermain Jawaban?, (4) bagaimanakah peningkatan hasil belajar siswa dalam pembelajaran IPA di kelas IV SD Negeri 10 Koto Jua Kecamatan Bayang melalui metode Bermain Jawaban?

Penelitian ini bertujuan mendeskripsikan: (1) Peningkatkan partisipasi bertanya siswa dalam pembelajaran IPA di kelas IV SD Negeri 10 Koto Jua Kecamatan Bayang melalui metode Bermain Jawaban, peningkatkan partisipasi menjawab siswa dalam pembelajaran IPA di kelas IV SD Negeri 10 Koto Jua Kecamatan Bayang melalui metode Bermain Jawaban, (3) peningkatkan partisipasi berdiskusi siswa dalam pembelajaran IPA di kelas IV SD Negeri 10 Koto Jua Kecamatan Bayang melalui metode Bermain Jawaban, (4) peningkatkan hasil belajar siswa dalam pembelajaran IPA di kelas IV SD Negeri 10 Koto Jua Kecamatan Bayang melalui metode Bermain Jawaban.

Penelitian tindakan kelas ini mempunyai manfaat yang cukup banyak, dan hasil penelitian dapat digunakan sebagai umpan balik dalam memperbaiki kegiatan pembelajaran di SD, adapun manfaat penelitian ini adalah sebagai berikut: (1) Bagi peneliti, menambah pengetahuan penulis tentang penggunaan metode Bermain Jawaban pada pelajaran IPA, (2) bagi sekolah dan guru SD, sebagai pedoman dalam penggunaan metode Bermain Jawaban dalam proses pembelajaran, (3) bagi siswa SD, membantu menumbuhkan kepercayaan diri untuk berpartisipasi dalam belajar sehingga dapat mengikuti pembelajaran dengan baik.

\section{B. METODE PENELITIAN}

Jenis penelitian yang digunakan peneliti adalah Penelitian Tindakan Kelas (PTK). Secara etimologis, ada tiga istilah yang berhubungan dengan PTK, yakni penelitian, tindakan, dan kelas

Penelitian tindakan kelas ini dilakukan di SDN 10 Koto Jua Kecamatan Bayang, dengan mempertimbangkan 
bahwa sekolah tersebut mau menerima inovasi pendidikan terutama dalam proses pembelajaran untuk peningkatan partisipasi siswa pada pembelajaran IPA. Subjek dalam penelitian ini adalah siswa kelas IV SDN 10 Koto Jua Kecamatan Bayang yang berjumlah 16 orang, yang terdiri dari 10 laki-laki dan 6 perempuan. Penelitian ini dilaksanakan pada semester II Tahun Ajaran 2012/2013, terhitung mulai dari waktu perencanaan sampai pembuatan laporan hasil penelitian.

Penelitian ini dilakukan dengan mengacu pada disain PTK yang dirumuskan Arikunto, dkk. (2010:16) yang terdiri dari empat komponen yaitu: perencanaan, pelaksanaan tindakan, observasi/pengamatan, dan refleksi

Sumber data penelitian ini adalah proses pembelajaran IPA yang meliputi perencanaan pembelajaran, perilaku guru dan siswa sewaktu pembelajaran berlangsung. Data diperoleh dari:

1. Siswa kelas IV SDN 10 Koto Jua Kecamatan Bayang, untuk mendapatkan data tentang partisipasi siswa dalam mengikuti pembelajaran.

2. Observer, untuk melihat tingkat keberhasilan pembelajaran IPA.

3. Guru yang bersangkutan, untuk melihat implementasi PTK baik dari siswa maupun guru.

Dalam penelitian ini, peneliti menggunakan beberapa instrumen yang digunakan untuk mengumpulkan data, yaitu:

\section{Lembar Aktivitas Guru}

2. Lembar Observasi Partisipasi Siswa

3. Tes Hasil Belajar

Data pemilihan ini dkumpulkan dengan menggunakan, observasi, wawancara dan hasil tes. Untuk masingmasingnya diuraikan sebagai berikut:

1. Observasi mengamati apa yang terjadi dalam proses pembelajaran ditandai dengan memberikan ceklis pada kolom yang terdapat pada lembar observasi.

2. Wawancara digunakan untuk memperkuat data observasi yang terjadi di kelas baik dari unsur guru maupun siswa.

3. Tes yang digunakan untuk memperkuat data observasi yang terjadi dalam kelas terutama dalam butir penguasaan materi pembelajaran dari unsur siswa.

Siswa dikatakan tuntas belajar apabila telah mencapai acuan standar Kriteria Ketuntasan Minimal (KKM) yang ditetapkan oleh sekolah tempat penelitian yaitu 65. Sedangkan indikator pada partisipasi siswa adalah:

1. Partisipasi siswa dalam bertanya meningkat menjadi $70 \%$ atau lebih.

2. Partisipasi siswa dalam menjawab pertanyaan meningkat menjadi $70 \%$ atau lebih. 
3. Partisipasi siswa dalam diskusi meningkat menjadi $70 \%$ atau lebih.

4. Ketuntasan hasil belajar siswa secara klasikal meningkat menjadi $70 \%$ atau lebih di atas nilai KKM.

5. Kemampuan guru melaksanakan pembelajaran meningkat mencapai nilai $70 \%$ atau lebih.

\section{HASIL DAN PEMBAHASAN}

\section{Deskripsi Kegiatan Pembelajaran Siklus I}

\section{a. Data Hasil Observasi Pelakasanaan Proses Pembelajaran Guru}

Metode Bermain Jawaban dalam pembelajaran IPA pada siklus pertama persentase $80 \%$ dan pertemuan kedua $80 \%$. Dapat disimpulan kalau kriteria dalam pengamatan Pelaksanaan Proses pembelajaran guru mendapatkan nilai baik.

\section{b. Hasil Observasi Partisipasi Siswa dalam Pembelajaran}

Data hasil observasi yang didapat menggunakan lembar observasi partisipasi siswa. Digunakan untuk melihat proses dan perkembangan partisipasi yang terjadi selama pembelajaran.

1. Siswa yang berdiskusi pada pertemuan 1 berjumlah 6 orang dengan persentase $37,50 \%$, sedangkan pada pertemuan 2 siklus I siswa yang berdiskusi berjumlah 9 orang dengan persentase $56,25 \%$. Sehingga diperoleh rata-rata persentase $46,87 \%$ dalam kategori kurang.
2. Siswa yang menjawab pertanyaan pada pertemuan 1 berjumlah 7 orang dengan persentase $43,75 \%$, sedangkan pada pertemuan 2 siswa menjawab pertanyaan berjumlah 10 orang dengan persentase $\quad 43,75 \%$. Sehingga diperoleh rata-rata persentase 53,12\% dalam kategori kurang.

3. Siswa yang menanggapi pertanyaan pada pertemuan 1 siklus I berjumlah 6 orang dengan persentase $37,50 \%$, sedangkan pada pertemuan 2 siklus I siswa yang menanggapi pertanyaan berjumlah 10 orang dengan persentase $43,75 \%$. Sehingga diperoleh rata-rata persentase $40,62 \%$ dalam kategori kurang.

\section{c. Data Hasil Belajar}

Hasil belajar siswa pada tes akhir siklus I siswa yang mengikuti tes hasil belajar adalah 16 orang. Sedangkan siswa yang tuntas dalam tes adalah 9 orang dan yang tidak tuntas adalah 7 orang. Persentase ketuntasan hasil belajar adalah $56,25 \%$, sedangkan target ketuntasan hasil belajar adalah $70 \%$

\section{a. Data Hasil Observasi Pelakasanaan Proses Pembelajaran Guru}

Metode bermain jawaban dalam pembelajaran IPA pada siklus kedua persentase $93,33 \%$ dan pertemuan kedua 93,33\%. Dapat disimpulan kalau kriteria dalam pengamatan pelakasanaan proses 
pembelajaran guru mendapatkan nilai sangat baik.

\section{b. Hasil Observasi Partisipasi Siswa dalam Pembelajaran}

Data hasil observasi yang didapat menggunakan lembar observasi partisipasi siswa. Digunakan untuk melihat proses dan perkembangan partisipasi yang terjadi selama pembelajaran.

1. Siswa yang berdiskusi pada pertemuan 1 berjumlah 11 orang dengan persentase $68,75 \%$, sedangkan pada pertemuan 2 siklus I siswa yang berdiskusi berjumlah 12 orang dengan persentase $75 \%$. Sehingga diperoleh rata-rata persentase $71,87 \%$ dalam kategori baik.

2. Siswa yang menjawab pertanyaan pada pertemuan 1 berjumlah 11 orang dengan persentase $68,75 \%$, sedangkan pada pertemuan 2 siswa menjawab pertanyaan berjumlah 12 orang dengan persentase $\quad 75,00 \%$. Sehingga diperoleh rata-rata persentase $71,87 \%$ dalam kategori baik.

3. Siswa yang menanggapi pertanyaan pada pertemuan 1 siklus I berjumlah 10 orang dengan persentase 32,25\%, sedangkan pada pertemuan 2 siklus I siswa yang menanggapi pertanyaan berjumlah 13 orang dengan persentase $81,25 \%$. Sehingga diperoleh rata-rata persentase $71,87 \%$ dalam kategori baik.

\section{c. Data Hasil Belajar}

Hasil belajar siswa pada tes akhir siklus I (terlampir) siswa yang mengikuti tes hasil belajar adalah 16 orang. Sedangkan siswa yang tuntas dalam tes adalah 13 orang dan yang tidak tuntas adalah 3 orang. Persentase ketuntasan hasil belajar adalah $81,25 \%$, sedangkan target ketuntasan hasil belajar adalah $70 \%$

\section{A. Pembahasan}

\section{Partisipasi Siswa}

Data hasil observasi yang didapat menggunakan lembar observasi partisipasi siswa. Digunakan untuk melihat proses dan perkembangan partisipasi yang terjadi selama pembelajaran. Hasil observasi observer terhadap partisipasi siswa dapat dilihat dalam pembelajaran.

Pembelajaran IPA menggunakan metode Bermain Jawaban yang dilaksanakan dapat terjadi peningkatan partisipasi siswa. Hal ini terbukti dari kenaikan rata-rata persentase untuk masing-masing indikator keberhasilan partisipasi siswa yang telah ditetapkan, seperti:

1. Siswa yang berdiskusi pada siklus 1 dengan persentase $46,87 \%$, sedangkan pada siklus II siswa yang berdiskusi berjumlah dengan persentase $71,87 \%$. Sehingga dalam kategori baik.

2. Siswa yang menjawab pertanyaan pada siklus 1 dengan persentase 53,12\%, sedangkan pada siklus II siswa yang 
berdiskusi berjumlah dengan persentase $71,87 \%$. Sehingga dalam kategori baik.

3. Siswa yang menanggapi pertanyaan pada siklus 1 dengan persentase 40,62\%, sedangkan pada siklus II siswa yang berdiskusi berjumlah dengan persentase $71,87 \%$. Sehingga dalam kategori baik.

\section{KESIMPULAN DAN SARAN}

Dari pembahasan yang dijelaskan, maka dapat di simpulkan sebagai berikut:

1. Terjadinya peningkatan siswa yang berdiskusi pada siklus 1 dengan persentase $46,87 \%$, menjadi $71,87 \%$ pada siklus 2 yang berada dalam kategori baik.

2. Terjadinya peningkatan siswa yang menjawab pertanyaan pada siklus 1 dengan persentase $53,12 \%$, menajdi $71,87 \%$ pada siklus 2 yang berada dalam kategori baik.

3. Terjadinya peningkatan siswa yang menanggapi pertanyaan pada siklus 1 dengan persentase 40,62\%, menjadi $71,87 \%$ pada siklus 2 yang berada dalam kategori baik.

Sehubungan dengan hasil penelitian yang diperoleh, maka peneliti memberikan saran dalam pelaksanaan pembelajaran dengan model bermain jawabam sebagai berikut:
1. Bagi siswa, agar meningkat partisipasi siswa dalam proses pembelajaran dengan berpartisipasi menjawab pertanyaan, menanggapi pertanyaan dan berdiskusi karena dengan siswa aktif maka akan menunjang semangat belajar.

2. Bagi guru yang melaksanakan pembelajaran dengan model bermain jawaban dapat memberikan kesempatan bagi siswa dalam proses pembelajaran yaitu mengajukan pertanyaan, menjawab pertanyaan dan menyimpulkan pelajaran dan dijadikan salah satu alternatif variasi dalam pelaksanaan pembelajaran.

3. Bagi peneliti yang mengambil judul ini sebaiknya dalam pembelajaran di variasikan dengan media gambar sehingga siswa tidak monoton atau jenuh dalam pembelajaran.

\section{E. DAFTAR PUSTAKA}

Arikunto, Suharsimi dkk. 2006. Penelitian Tindakan Kelas. Jakarta: Bumi Aksara

Asma, Nur. 2002. Model Pembelajaran Kooperatif. Padang: UNP Press Padang.

BSNP. 2007. Kurikulum Tingkat Satuan Pendidikan Sekolah Dasar. Jakarta: BSNP

Diyanto, 2006. Penerapan Model Pembelajaran Cooperative Learning Melalui Tipe Bermain Jawaban dalam Upaya Meningkatkan Hasil Belajar Siswa 
Kelas IV SDN 20 Kumango, Kabupaten Tanah Datar. Padang: UNP.

Hamalik, Oemar. 2007. Proses Belajar Mengajar. Jakarta: Bumi Aksara.

Maslichah Asy'ari. 2006. Penerapan Pendekatan Sains Teknologi Masyarakat Dalam Pembelajaran Sains Di SD. Yogyakarta: Universitas Sanata Dharma.

Mulyasa,E. 2006. Kurikulum Yang Disempurnakan. Bandung: Remaja Rosdakarya

Pebriyenni. 2009. Pembelajaran IPS II (Kelas Tinggi). Padang: kerjasama Dikti- Depdiknas dan Jurusan PGSD FKIP Bung Hatta.
Sanjaya, Wina. 2008. Kurikulum Pembelajaran. Jakarta: Prenada Media Grup.

Septiati, Amalia Dkk. 2008. Pembelajaran IPA di SD. Jakarta: Universitas Terbuka

Slavin, Robert. E. 2005. Cooperative Learning (Teori Riset dan Praktik). Bandung:Nusamedia.

Sudjana, Nana. 2002. Metode Statistik. Bandung: Tarsindo.

Taniredja Tukiran, dkk. 2010. Penelitian Tindakan Kelas. Bandung: Alfabeta.

Trianto. 2012. Model Pembelajaran Terpadu. Jakarta: Bumi Aksara.

Zaini, Hisyam.dkk. 2008. Strategi Pembelajaran Aktif. Yogyakarta: Pustaka Insan Madani. 